\title{
COMPARATIVE ANATOMY OF LEAF AND SPATHE OF NINE SPECIES OF ANTHURIUM (SECTION UROSPADIX; SUBSECTION FLAVESCENTIVIRIDIA) (ARACEAE) AND THEIR DIAGNOSTIC POTENTIAL FOR TAXONOMY
}

\author{
André Mantovani ${ }^{1} \&$ Thaís Estefani Pereira ${ }^{2}$
}

\begin{abstract}
(Comparative anatomy of leaf and spathe of nine species of Anthurium (section Urospadix; subsection Flavescentiviridia) (Araceae) and their diagnostic potential for taxonomy) Leaf and spathe anatomy of seven species and two varieties of the genus Anthurium (section Urospadix; subsection Flavescentiviridia) were analyzed. Plant material was collected from different locations in Brazil and cultivated under identical glasshouse conditions in the Rio de Janeiro Botanical Garden. Our attempt is to evaluate the diagnostic potential of leaf and spathe anatomy for taxonomic purposes. Leaves presented smooth cuticle, polygonal epidermal cells randomly disposed in paradermal view, periclinal divisions of epidermal cells in transversal view, non-raised stomata, collenchyma, sclerenchymatic bundle sheaths and raphides in the mesophyll. The spathe presented cuticular striations; rectangular and elongated cells in parallel rows; raised stomata; absence of collenchyma, raphides and sclerenchymatic bundle sheaths and presence of sclerenchyma as fibre caps under phloem. Clustering analysis based on leaf and spathe anatomical characters, revealed that the spathe can give a better resolution for segregation of species groups.
\end{abstract}

Key-words: leaf, spathe, anatomy, taxonomy, Anthurium, Araceae.

\section{Resumo}

(Anatomia comparada da folha e espata de nove espécies de Anthurium (seção Urospadix; subseção Flavescentiviridia) (Araceae) e seu potencial para diagnóstico na taxonomia) São apresentados dados relativos à anatomia da lâmina foliar e espata de sete espécies e duas variedades do gênero Anthurium pertencentes à seção Urospadix; subseção Flavescentiviridia. Os indivíduos foram coletados nos estados do Rio de Janeiro, São Paulo e Minas Gerais, e aclimatados no Instituto de Pesquisas Jardim Botânico do Rio de Janeiro. O objetivo deste estudo é comparar anatomicamente lâmina foliar e espata, visando detectar qual das duas estruturas é mais útil à diagnose taxonômica das espécies estudadas. Observa-se nas folhas a presença de cutícula lisa e células epidérmicas dispostas ao acaso, estômatos nivelados com a epiderme, divisões periclinais em células epidérmicas, além de ráfides no mesofilo e bainha esclerenquimática nos feixes vasculares. Já quanto à espata observa-se cutícula estriada, células alongadas e ordenadas de forma paralela, estômatos por vezes elevados, ausência de ráfides e presença de calota de fibras apenas junto ao floema, quando não ausentes. A análise de agrupamento para folha e espata revelou maior poder de resolução com base em caracteres anatômicos da espata; além dos grupos formados com base nos caracteres anatômicos da folha não serem consistentes taxonomicamente. Sugere-se portanto que a espata apresenta maior valor diagnóstico ao nível anatômico para subsidiar estudos taxonômicos do gênero Anthurium.

Palavras-chave: folha, espata, anatomia, taxonomia, Anthurium, Araceae.

\section{INTRODUCTION}

The family Araceae presents 2823 species in 106 genera (Govaerts et al. 2002). The genus Anthurium, described by Schott in 1829 , is the largest in the family, with approximately 1000 species. In 1878 Engler divided the genera in 18 sections, and in 1898 he determined six subsections for the section
Urospadix (Coelho 2004). One of these subsections is Flavescentiviridia with 26 of its 32 taxa occurring on the southeastern Brazil (Coelho 2004).

Historical and experimental events justify improved efforts for taxonomical and anatomical studies in the genus Anthurium. Schott's herbarium, with type specimens, was

Artigo recebido em 03/2005. Aceito para publicação em 11/2005.

${ }^{1}$ Author for correspondence: André Mantovani, Instituto de Pesquisas Jardim Botânico do Rio de Janeiro, Programa Zona Costeira, Rua Pacheco Leão 915, CEP 22460-030, Jardim Botânico, Rio de Janeiro, Brasil, andre@j.jbrj.gov.br ${ }^{2}$ Bolsista Iniciação Científica PIBIC/CNPq. 
destroyed during the World War II, leaving just lectotypes (Mayo et al. 1997). Both Schott and Engler described many species from cultivated material that was not deposited in herbaria and was subsequently lost. Engler (1905) also described and determined species using characters of high morphological plasticity like length of petiole, leaf thickness and leaf area. The genus has not been revised until recently, by Coelho (2004), who worked with section Urospadix, subsection Flavescentiviridia.

Since the classical work by Solereder \& Mayer (1928), there have been many publications on leaf anatomy of Araceae, and an extensive list of references can be found on French et al. (1995) and Keating (2000, 2003). However, research on the leaf anatomy of Anthurium are relatively few (Lindorf 1980, Rada \& Jaimez 1992, Mantovani 1999a, b).

The recent extensive revision on the anatomy of Araceae (Keating 2002) not only shows the existence of useful leaf characters for diagnostic purposes, but applies them to a phylogenetic approach for the family. However, little information is presented in relation to the anatomy of the spathe.

The objectives of this paper were to describe leaf and spathe anatomy, and to comparatively evaluate the diagnostic potential of their anatomy for taxonomic purposes in the genus Anthurium.

\section{Material AND Methods}

\section{Study site and species}

Individuals from Anthurium species were collected in different locations in Brazil and cultivated under identical glasshouse conditions in the Rio de Janeiro Botanical Garden, Brazil. Nine taxa were studied: $A$. comtum Schott (RB 353492), A. harrisii var. consanguineum (Kunth.) Engl. (RB 354740), A. harrisii var. assimile (Schott) Engl. (RB 353496), A. harrisii (Graham) Endl. (RB 414682), A. regnellianum Engl. (RB 383406), A. sellowianum Kunth (RB 364273), A. beyrichianum Kunth (RB 353489), A. parasiticum (Vell.) Stellfeld (RB 353493) and Anthurium sp. nov. ined. (RB 360300), that followed recent revision of Coelho (2004). The climate in the study area is Am (sensu Koppen) (Galante 1984 apud Embrapa 1992), with precipitation concentrated in summer and reduced during winter, with mean annual rainfall of $1075 \mathrm{~mm}$. The mean annual temperatures during summer and winter are respectively $29^{\circ} \mathrm{C}$ and $22^{\circ} \mathrm{C}$.

\section{Anatomical analysis}

For each individual plant, leaves and inflorescence were collected, preserved in humid plastic bags and sent to laboratory. Entire leaves, spathe and spadix were fixed in FAA 70. Sections obtained at mid level from leaves and spathe were fixed in a solution of glutaraldehyde $4 \%$ and formaldehyde $1 \%$ (McDowel 1978) in a sodium phosphate buffer 0.1M, pH 7.2. Materials fixed in FAA were used to obtain hand paradermal sections that were stained with safranin (Johansen 1940). Cross sections were obtained from material fixed in glutaraldehyde solution, after dehydration in ethylic series and inclusion in hydroxyethylmethacrylate (Gerrits \& Smid 1983). Sections at 2-4 mm thickness were realized at a Spencer microtome, and stained with Toluidine Blue O (O'Brien \& McCully 1981). Photomicrographs were obtained with an Olympus BX-50 light microscope.

The classification of cells and tissues followed the nomenclature proposed by Keating $(2000,2002)$.

\section{Statistics}

Leaf and spathe anatomy were compared in relation to their diagnostic capacity using hierarchical clustering analysis. Only anatomical traits with recognized low plasticity were used here. Anatomical traits were resumed to binary 0 and 1 relative to absence or presence. The Euclidean distance coefficient was applied, followed by UPGMA algorithm, and cophenetic values higher than 
Table 1. Leaf anatomical characters from species of Anthurium. Paradermal view of the epidermises. Size and sinuosity of anticlinal walls; stomatal types and size of subsidiary cells from the brachyparacitic stomata. Abbreviations: $\mathrm{ABP}=$ anfibraquiparacytic; $\mathrm{BP}=$ braquiparacytic; $\mathrm{BPT}=$ braquiparatetracytic; $\mathrm{BPH}=$ braquiparahexacytic; $\mathrm{BPO}=$ braquiparaoctocytic; $\mathrm{UNI}=$ unipolar.

\begin{tabular}{|c|c|c|c|c|c|}
\hline \multirow{3}{*}{$\begin{array}{l}\text { Characters/ } \\
\text { Species } \\
\text { braquiparacytic } \\
\text { surface) }\end{array}$} & \multirow{3}{*}{$\begin{array}{l}\text { Epidermal cells } \\
\text { from the } \\
\text { abaxial surface }\end{array}$} & \multirow{3}{*}{$\begin{array}{l}\text { Epidermal cells } \\
\text { from the }\end{array}$} & \multirow{3}{*}{$\begin{array}{c}\text { Stomatal types } \\
\text { (abaxial surface) }\end{array}$} & \multicolumn{2}{|c|}{ Size of the subsidiary } \\
\hline & & & & & from \\
\hline & & & & stomata & (abaxial \\
\hline A. sellowianum & $\begin{array}{l}\text { Short; straight } \\
\text { to undulate } \\
\text { anticlinal walls }\end{array}$ & $\begin{array}{l}\text { Short; straight } \\
\text { to undulate } \\
\text { anticlinal walls }\end{array}$ & $\begin{array}{l}\text { ABP; BP; } \\
\text { BPH; BPO }\end{array}$ & Large & \\
\hline A. comtum & $\begin{array}{l}\text { Short; straight } \\
\text { to undulate } \\
\text { anticlinal walls }\end{array}$ & $\begin{array}{l}\text { Short, straight } \\
\text { anticlinal walls }\end{array}$ & $\begin{array}{l}\mathrm{ABP} ; \mathrm{BP} ; \\
\mathrm{BPH}\end{array}$ & Large & \\
\hline A. beyrichianum & $\begin{array}{l}\text { Short; straight } \\
\text { to undulate } \\
\text { anticlinal walls }\end{array}$ & $\begin{array}{l}\text { Short; straight } \\
\text { to undulate } \\
\text { anticlinal walls }\end{array}$ & ВР; ВРТ; ВРН & Large & \\
\hline $\begin{array}{l}\text { A. harrisii var. } \\
\text { assimile }\end{array}$ & $\begin{array}{l}\text { Short; undulate } \\
\text { anticlinal walls }\end{array}$ & $\begin{array}{l}\text { Short, straight } \\
\text { anticlinal walls }\end{array}$ & $\begin{array}{l}\text { ABP; BP; BPH; } \\
\text { BPO; UNI }\end{array}$ & Large & \\
\hline $\begin{array}{l}\text { Anthurium harrisii } \\
\text { var. consanguineum }\end{array}$ & $\begin{array}{l}\text { Short, straight } \\
\text { anticlinal walls }\end{array}$ & $\begin{array}{l}\text { Short, straight } \\
\text { anticlinal walls }\end{array}$ & BP; BPH; UNI & Large & \\
\hline A. harrisii & $\begin{array}{l}\text { Short; undulate } \\
\text { anticlinal walls }\end{array}$ & $\begin{array}{l}\text { Short; straight } \\
\text { to undulate } \\
\text { anticlinal walls }\end{array}$ & $\begin{array}{l}\text { ABP, BP; } \\
\text { BPH; UNI }\end{array}$ & Large & \\
\hline A. parasiticum & $\begin{array}{l}\text { Short; straight } \\
\text { to undulate } \\
\text { anticlinal walls }\end{array}$ & $\begin{array}{l}\text { Short; straight } \\
\text { to undulate } \\
\text { anticlinal walls }\end{array}$ & BP; BPH; UNI & Large & \\
\hline Anthurium sp. nov. & $\begin{array}{l}\text { Short; undulate } \\
\text { anticlinal walls }\end{array}$ & $\begin{array}{l}\text { Short; undulate } \\
\text { anticlinal walls }\end{array}$ & $\mathrm{BP} ; \mathrm{BPH}$ & Large & \\
\hline A. regnellianum & $\begin{array}{l}\text { Short; straight } \\
\text { to undulate }\end{array}$ & $\begin{array}{l}\text { Short; straight } \\
\text { to undulate }\end{array}$ & $\mathrm{BP} ; \mathrm{BPH}$ & Large & \\
\hline
\end{tabular}

0.8 were considered sigeififigantllsValentitielinal wdes found in just one surface (Table 1). The 2000). stomata subsidiary cells are large in all species

\section{Results}

\section{Leaf anatomy}

Paradermal sections of the adaxial and abaxial epidermal surfaces are shown in Fig. $1(\mathrm{C}-\mathrm{H})$. The cells are short and polygonal, with straight to undulate anticlinal walls. Stomata are found on both surfaces, but at adaxial surface restricted to midrib and margins. Stomata types found on the abaxial surface are brachy-paracytic and its variations (amphybrachy-paracytic, brachypara-tetra, hexa and octocytic) and the unipolar type (Fig. 1, C-H). Two to five distinct types could
(Fig. 1H). Stomata complex distribuition is random on the abaxial surface and parallel to the elongated epidermal cells on the adaxial surface of the midrib.

The leaf epidermis of all species are monolayered. They are similar in cross section (Fig. 2, B-C) constituted by tabular cells with straight to slightly convex outer periclinal walls covered by a smooth cuticle. The species $A$. harrisii var. consanguineum and A. comtum present periclinal divisions in some epidermal cells of the adaxial surface (Fig. 2A).

The mesophyll is dorsiventral in all 

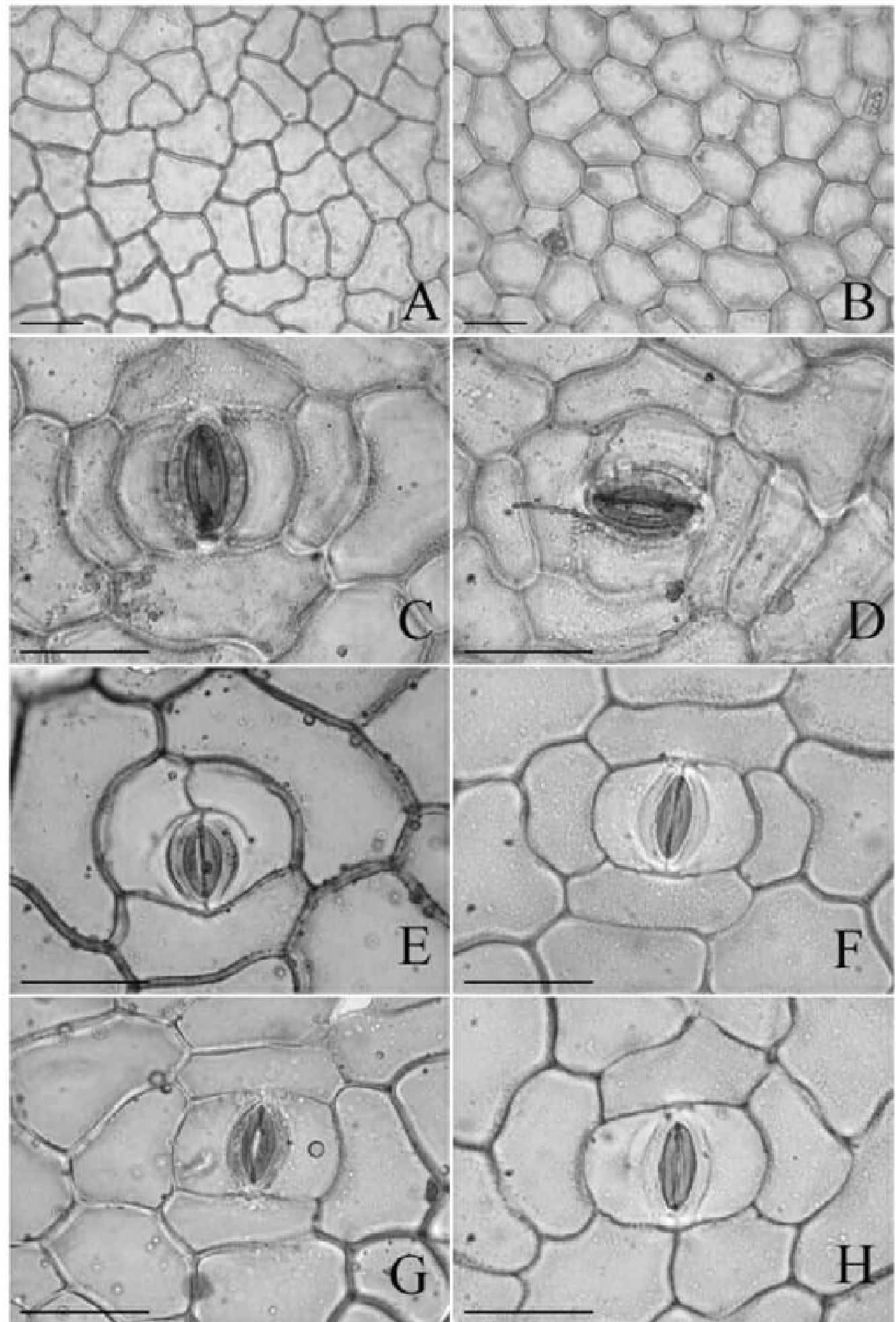

Figure 1 - Leaf epidermis. Adaxial (A, B) and abaxial (C-H)surfaces in paradermal view. A. epidermal cells with undulate anticlinal walls. (Anthurium sp. nov.); B. epidermal cells with straight anticlinal walls (A. harrisii var. assimile); C. amphibrachyparacitic stomata. (A. harrisii); D. brachyparaoctocitic stomata. (A. harrisii var. assimile); E. unipolar stomata. (A. parasiticum); F. brachyparahexacitic stomata. (Anthurium sp. nov.); G. brachyparatetracitic stomata. (A. harrisii); H. brachyparacitic stomata. Note narrow subsidiary cells. (Anthurium sp. nov.). Bar $=20 \mu \mathrm{m}$. 


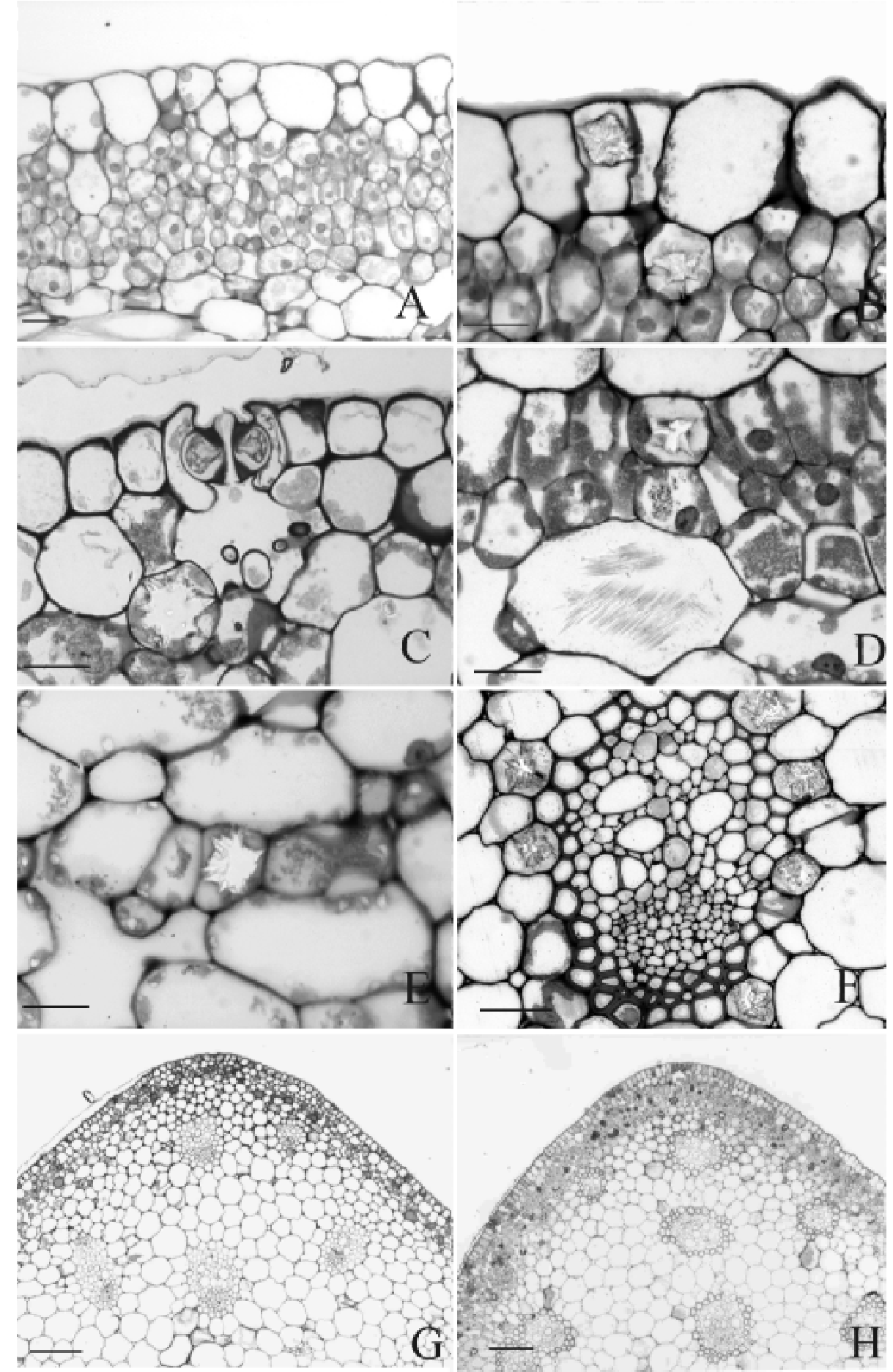

Figure 2 - Leaf mesophyll. Transversal section. A. periclinal divisions in epidermal cells from the adaxial surface. Note multilayered palisade parenchyma composed by short cells. (A. harrisii var. consanguineum); B. smooth cuticle above adaxial surface of the epidermis. Note presence of druses on epidermis and palisade parenchyma. (A. harrisii); C. stomata at same level of epidermal cells from abaxial surface. (A. harrisii var. assimile); D. raphides on the spongy parenchyma. (A. harrisii var. consanguineum); E. druses on the spongy parenchyma. (A. harrisii var. assimile); F. colateral vascular bundles with sclerenchymatic fiber sheath. Note thicker fiber cells near phloem. (A. parasiticum); G. adaxial surface of midvein. Note absence of palisade parenchyma; H. adaxial surface of midvein. Note presence of palisade parenchyma, evident as a continuous and deeply stained region below the epidermis. Bar $=20 \mu \mathrm{m}$. 
species (Fig. 2A). The palisade parenchyma has four to five layers of cells and the spongy parenchyma is constituted by 12 to 18 layers of cells. On the adaxial surface of the midrib, the palisade parenchyma is usually interrupted by a collenchymatous tissue in almost all species (Fig. 2G). However, typical collenchyma cells are found only in the abaxial region of the midrib. Although presenting thick periclinal walls in transversal view, collenchymatous cells on the adaxial surface are not typically elongated in longitudinal view (Fig. 2G). In A. regnellianum, collenchymatous cells are poorly developed and continuous palisade parenchyma occurs adjacent to the adaxial surface at the midrib (Fig. 2H).

The sclerenchyma is represented only by the fibres from the sclerenchymatic bundle sheaths (Fig. 2F). Leaves have reticulated venation. In cross section, vascular bundles are collateral and constituted by several proto and metaxylem cells adjacent to a semicircular phloem (Fig. 2F).

Raphides of calcium oxalate crystals are found with low frequency, but druses are very frequent (Table 2). The raphides occur rarely and only on the spongy parenchyma (Fig. 2D) while the druses are frequent in all the mesophyll and in both surfaces (Fig. 2, C-E). Spathe anatomy

Paradermal sections of the adaxial and abaxial surfaces of the spathe are shown in Fig. 3. Epidermal cells are rectangular, varying from short to elongate but always oriented in longitudinal parallel rows. Most of the species present short cells on the adaxial surface and medium or elongated cells on the abaxial surface (Table 3 ). Medium sized cells are found in A. parasiticum and short sized cells in A. regnellianum. Anticlinal walls in paradermal view vary from straight to sinuous and some epidermal cells present oblique edges (Fig. 3B).

Stomata are present on both spathe surfaces. The brachyparacytic type (Fig. 3H) and its variations (amphibrachyparacytic (Fig. 3G), brachypara-tetracytic, -hexacytic (Fig. 3F), and octocytic (Fig. 3E)), as well as the unipolar (Fig. 3D) and the anomocytic types

Table 2. Leaf anatomical characters from species of Anthurium. Transversal view. Data are presence (1) or absence (0) selected characters. Numbers represent: $1=$ druse on both epidermises; $2=$ druse on palisade parenchyma; $3=$ druse on spongy parenchyma; $4=$ raphides on chlorenchyma; $5=$ presence of palisade parenchyma on the adaxial surface on the midvein; $6=$ absence of palisade parenchyma on the adaxial surface on the midvein; $7=$ stomata on adaxial surface of the epidermis, $8=$ stomata on the abaxial surface of the epidermis; $9=$ cell periclinal divisions on the adaxial surface of the epidermis; $10=$ presence of collenchymatous tissue on the adaxial surface of the midvein; $11=$ smooth cuticle on the adaxial surface of the epidermis; $12=$ smooth cuticle on the abaxial surface of the epidermis.

\begin{tabular}{|c|c|c|c|c|c|c|c|c|c|c|c|c|}
\hline Characters/Species & 1 & 2 & 3 & 4 & 5 & 6 & 7 & 8 & 9 & 10 & 11 & 12 \\
\hline A. sellowianum & 0 & 1 & 1 & 0 & 0 & 1 & 1 & 1 & 1 & 0 & 1 & 1 \\
\hline A. comtum & 1 & 1 & 1 & 1 & 1 & 0 & 0 & 1 & 1 & 0 & 1 & 1 \\
\hline A. beyrichianum & 0 & 1 & 1 & 1 & 1 & 0 & 1 & 1 & 0 & 1 & 1 & 1 \\
\hline $\begin{array}{l}\text { A. harisii var. } \\
\text { assimile }\end{array}$ & 0 & 1 & 1 & 1 & 0 & 1 & 1 & 1 & 0 & 1 & 1 & 1 \\
\hline $\begin{array}{l}\text { A. harisii var. } \\
\text { consanguineum }\end{array}$ & 0 & 1 & 1 & 1 & 0 & 1 & 1 & 1 & 1 & 1 & 1 & 1 \\
\hline A. harisii & 1 & 1 & 1 & 0 & 0 & 1 & 1 & 1 & 0 & 1 & 1 & 1 \\
\hline A. parasiticum & 0 & 1 & 1 & 0 & 0 & 1 & 1 & 1 & 0 & 1 & 1 & 1 \\
\hline Anthurium sp. nov. & 0 & 1 & 1 & 0 & 0 & 1 & 1 & 1 & 0 & 1 & 1 & 1 \\
\hline A. regnelianum & 0 & 1 & 1 & 0 & 1 & 1 & 1 & 1 & 0 & 0 & 1 & 1 \\
\hline
\end{tabular}




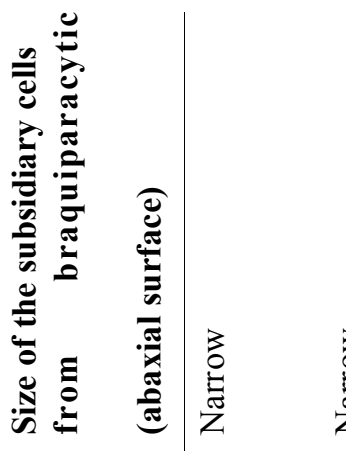

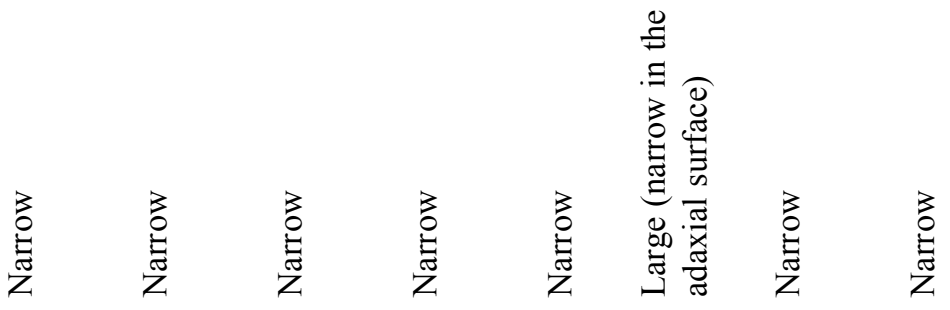<smiles>[CH]1[CH]CC1</smiles>

z

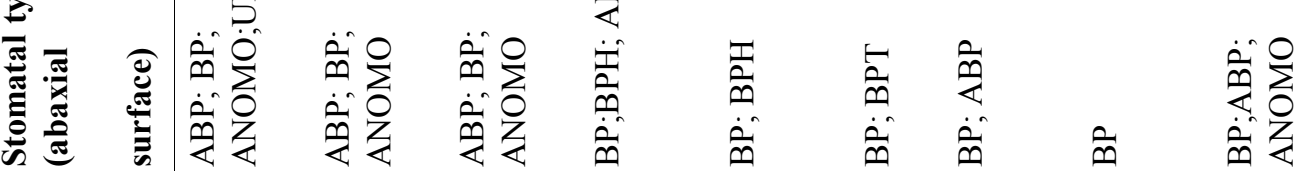

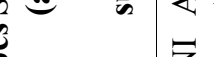

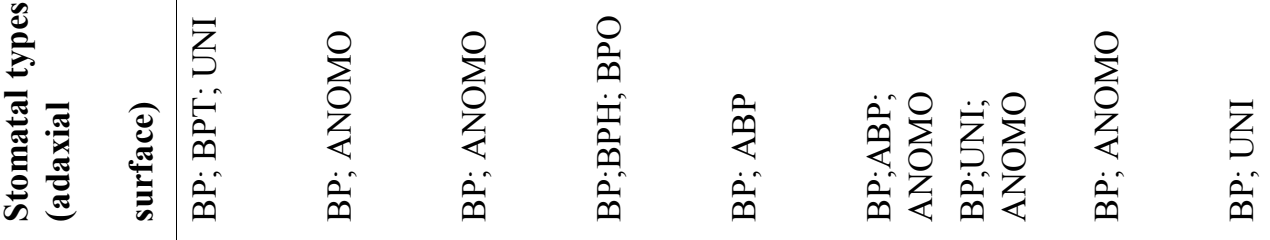

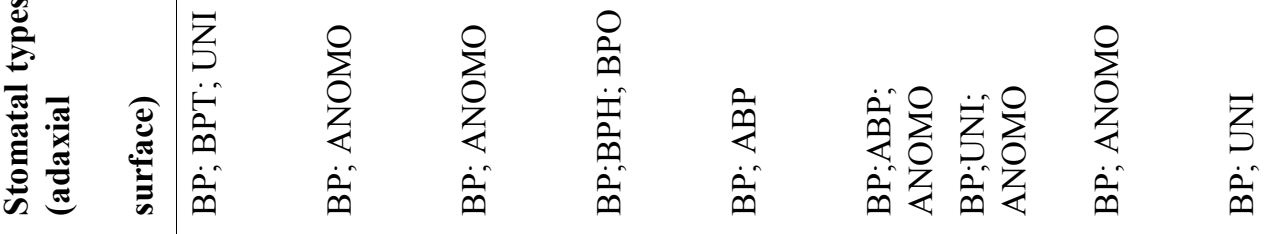

西

空

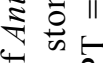

is

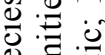

क力

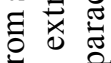

离范

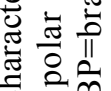

可

$\overline{\bar{\pi}}$

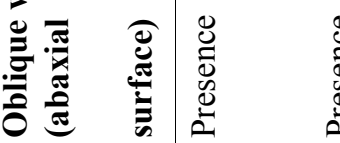

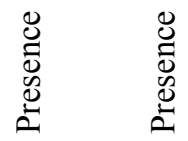

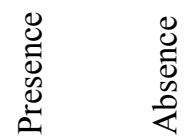

$\begin{array}{ll}0 & 0 \\ 0 & 0 \\ 0 & 0 \\ 0 & 0 \\ 0 & 0 \\ 0 & 0\end{array}$

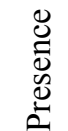

0
0
0
0
0
0

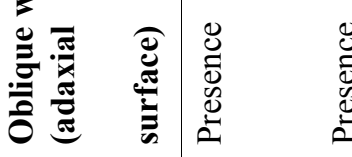

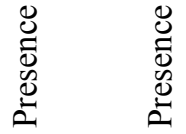

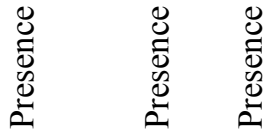

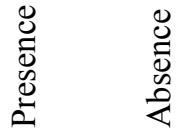

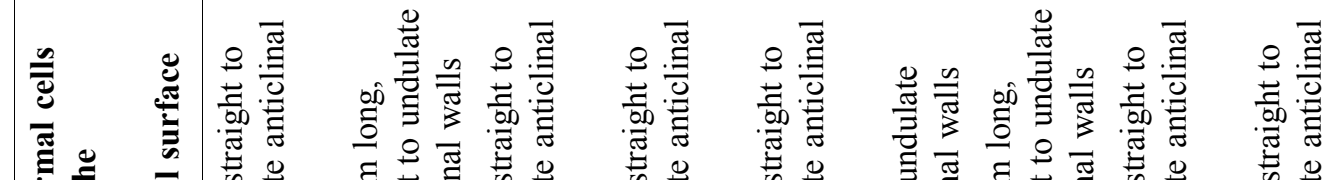

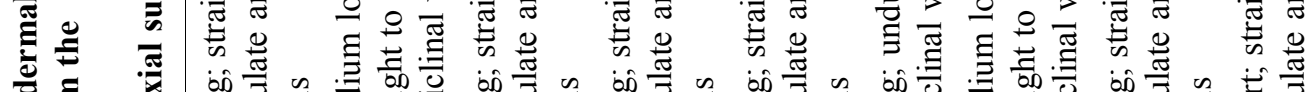

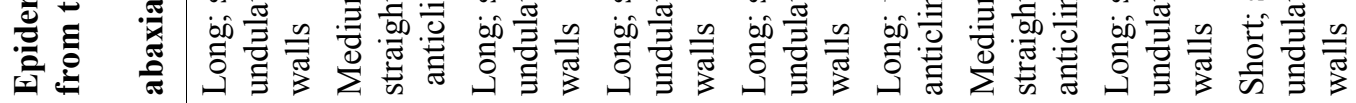
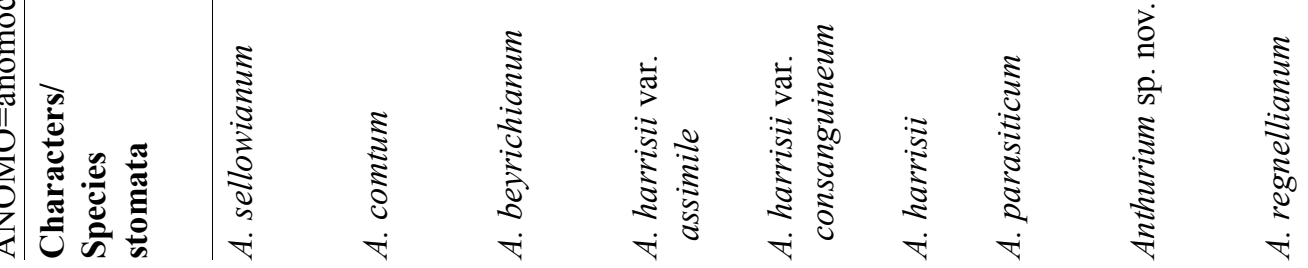

Rodriguésia 56 (88): 145-160. 2005 

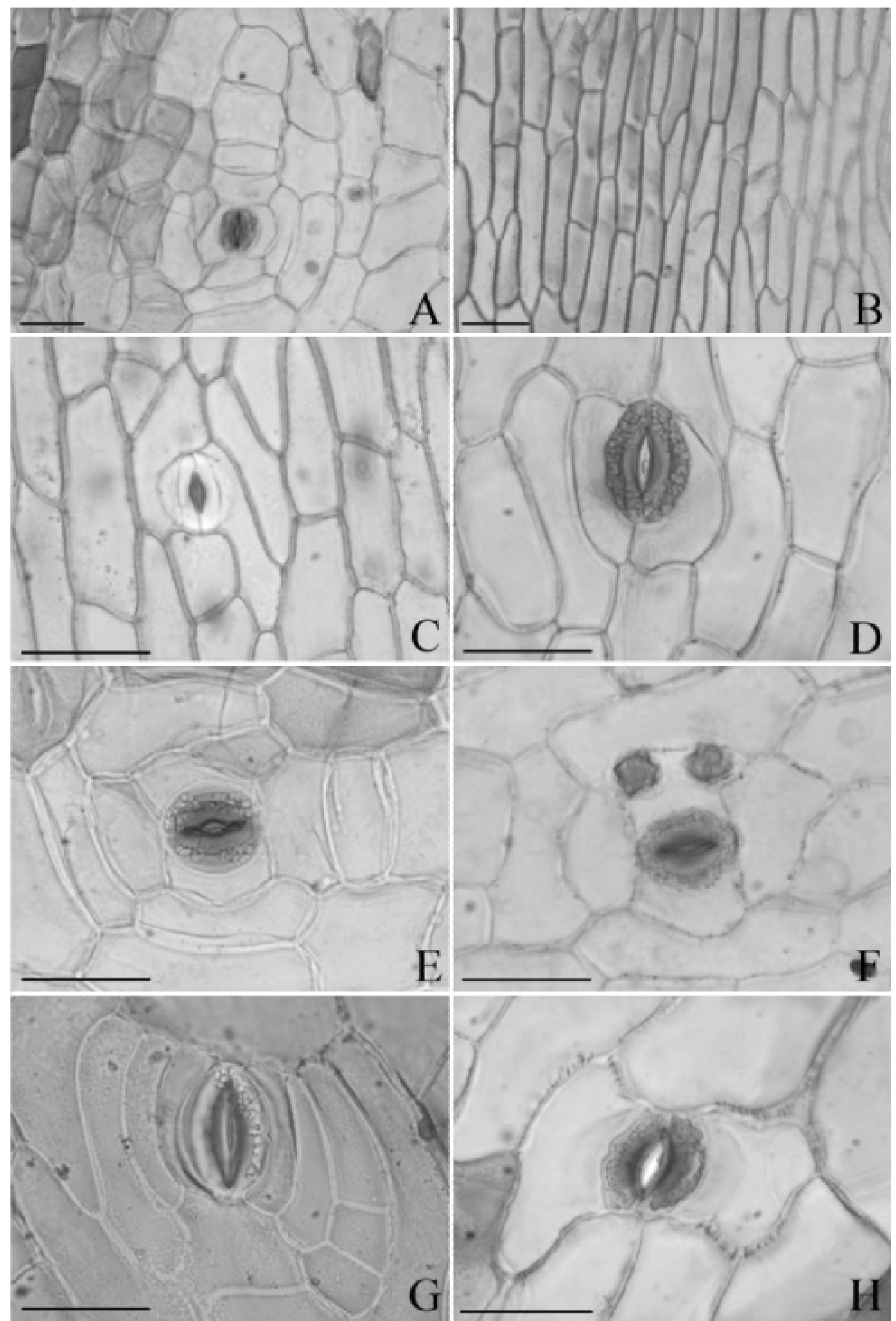

Figure 3 - Spathe epidermis. Adaxial and abaxial surfaces in paradermal view. A. parallel rows of short epidermal cells. Note straight to undulate anticlinal walls. (A. harrisii var. assimile; adaxial surface); B. parallel rows of long epidermal cells. Note oblique orientation of anticlinal walls in the polar extremities of the cells. (A. harrisii var. assimile; abaxial surface); C. anomocitic stom ata. (A. regnelianum; abaxial surface); D. unipolar stomata. (A. parasiticum; abaxial surface); E. brachyparaoctocitic stomata. (A. harrisii var. assimile; abaxial surface); F. brachyparahexacitic stomata. (A. harrisii var. assimile; abaxial surface); G. amphibrachyparacitic stomata. (A. parasiticum; abaxial surface); H. brachyparacitic stomata. Note large subsidiary cells. (A. parasiticum; abaxial surface). Bar $=20 \mu \mathrm{m}$. 


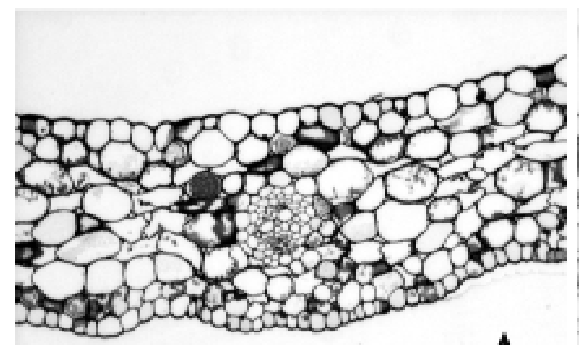

A
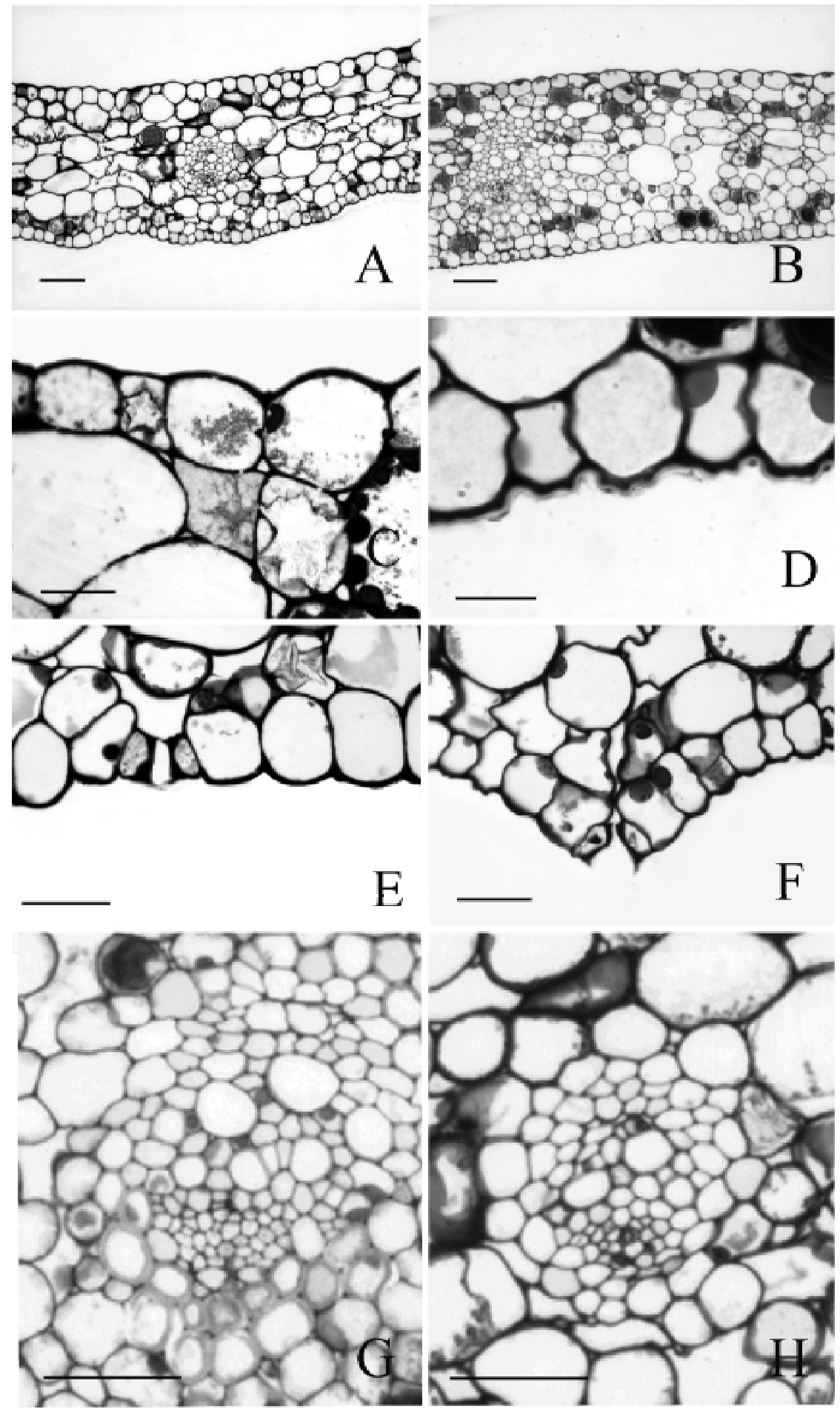

Figure 4 - Spathe mesophyll. Transversal section. A. uniform mesophyll with highly compacted cells. Note mounds on the abaxial surface. (Anthurium sp. nov.); B. uniform mesophyll with intercellular spaces. Note straight abaxial surface. ( $A$. regnelianum); C. druse oxalate crystals occurring on the epidermis and parenchyma. (A. harrisii); D. cuticular striations on the abaxial surface. (A. regnelianum); E. stomata on the abaxial surface level with other epidermal cells. (A. harrisii var. assimile); F. stomata no the abaxial surface above other epidermal cells. (Anthurium sp. nov.); G. colateral vascular bundles with fiber cap above phloem. (A. harrisii var. consanguineum); H. colateral vascular bundle without fiber cap. (Anthurium sp. nov.). Bar $=20 \mu \mathrm{m}$. 
(Fig. 3C) are found. One to four different types of stomata are found on each epidermal surface. The brachyparacytic type was found in all species. The brachyparatetracytic type is found only in A. harrisii and A. sellowianum and the brachyparaoctocytic one in $A$. harrisii var. assimile.

The brachyparacytic stomata present short subsidiary cells in all species, but $A$. parasiticum presents large subsidiary cells on the abaxial epidermal surface. The orientation of the guard cells was always parallel to the other epidermal cells.

All species present a monolayered epidermis constituted by tabular cells with straight to convex periclinal walls (Figs. 4, A-F). Only in A. regnellianum the epidermal cells from the abaxial surface are somehow columnar, taller than wide. The abaxial cuticle
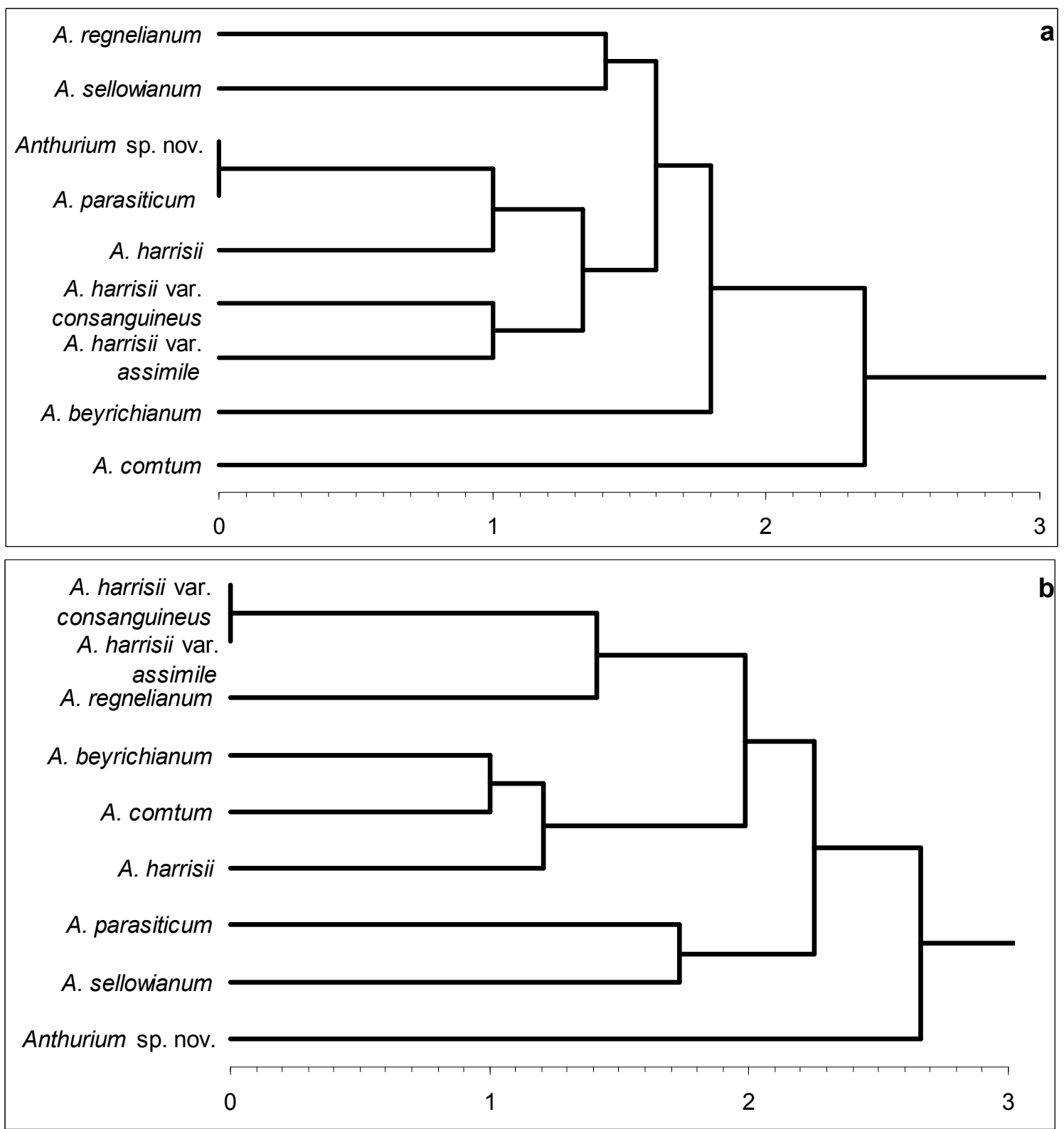

Figure 5 - Clustering analysis obtained with Euclidean distance and UPGMA algorithm, based on the presence or absence of distinct anatomical characters. a. leaf; b. spathe. 
Table 4. Spathe anatomical characters from species of Anthurium. Transversal view. Data are presence (1) or absence ( 0$)$ of selected characters. Numbers represent: $1=$ druse on both epidermises; $2=$ tabular cells in the abaxial surface of the epidermis; $3=$ stomata on the adaxial surface of the epidermis; $4=$ stomata on the abaxial surface of the epidermis; $5=$ stomata above epidermal cells on the abaxial surface; $6=$ stomata level with epidermal cells; $7=$ fiber caps; $8=$ mesophyll with large intercelular spaces; $9=$ faint cuticle striations on the abaxial surface of the epidermis; $10=$ striated on the abaxial surface of the epidermis; 11 = compact mesophyll; 12 = tall epidermal cells on the abaxial surface; $13=$ mounds on the abaxial surface of the epidermis.

\begin{tabular}{|c|c|c|c|c|c|c|c|c|c|c|c|c|c|}
\hline $\begin{array}{l}\text { Characters/ } \\
\text { Species }\end{array}$ & 1 & 2 & 3 & 4 & 5 & 6 & 7 & 8 & 9 & 10 & 11 & 12 & 13 \\
\hline A. sellowianum & 0 & 1 & 0 & 1 & 1 & 0 & 1 & 0 & 1 & 0 & 1 & 0 & 0 \\
\hline A. comtum & 0 & 1 & 1 & 1 & 0 & 1 & 1 & 0 & 1 & 0 & 1 & 1 & 0 \\
\hline A. beyrichianum & 1 & 1 & 1 & 1 & 0 & 1 & 1 & 0 & 1 & 0 & 1 & 1 & 0 \\
\hline $\begin{array}{l}\text { A. harisii var. } \\
\text { assimile }\end{array}$ & 0 & 1 & 1 & 1 & 0 & 1 & 1 & 0 & 0 & 1 & 1 & 0 & 0 \\
\hline $\begin{array}{l}\text { A. harisii var. } \\
\text { consanguineum }\end{array}$ & 0 & 1 & 1 & 1 & 0 & 1 & 1 & 0 & 0 & 1 & 1 & 0 & 0 \\
\hline A. harisii & 1 & 1 & 1 & 1 & 0 & 1 & 1 & 0 & 1 & 0 & 1 & 0 & 0 \\
\hline A. parasiticum & 1 & 1 & 1 & 1 & 1 & 0 & 1 & 0 & 1 & 0 & 1 & 0 & 1 \\
\hline Anthurium sp. nov. & 0 & 0 & 1 & 1 & 1 & 0 & 0 & 0 & 0 & 1 & 1 & 1 & 1 \\
\hline A. regnelianum & 0 & 1 & 1 & 1 & 0 & 1 & 1 & 1 & 0 & 1 & 0 & 0 & 0 \\
\hline
\end{tabular}

is smooth to ornamented, presenting few to frequent striations (Fig. 4D). On the species $A$. regnellianum and $A$. parasiticum the leaf abaxial surface is mounded (Fig. 4A).

The stomata in transverse section are on the same level of other epidermal cells (Fig. 4E), but, on the abaxial surface of $A$. sellowianum and $A$. regnellianum, they are positioned above the epidermal level (Fig. 4F).

The mesophyll is uniform, not differentiated in palisade and spongy tissue, and highly compacted in all species (Fig. 4A). However, the mesophyll of $A$. regnellianum have large intercellular spaces (Figure 4B).

Sclerenchyma on the spathe is represented only by fibres close to the vascular bundles forming a cap (Fig. 4G), with the exception of $A$. regnellianum, that does not present fibres (Fig. 4H). Spathe venation is parallel, with collateral vascular bundles with proto and metaxylem cells adjacent to a semicircular phloem (Figs. 4, G-H).

Calcium oxalate crystals are represented by druses occurring in all mesophyll and in both epidermal surfaces (Figs. 4, C-E). Raphides were not found. Tannin idioblasts occurred along all the mesophyll.

\section{Statistical analysis}

Clustering analysis reveals distinct results for the leaf and spathe anatomy (Fig. $5)$. For the leaf anatomy, coefficients vary from 0.0 to 2.6, the UPGMA values vary from 0.0 to 2.3 and the cophenetic index is 0.9 $(\mathrm{p}<0.01)$. However, taxonomically distinct species are considered as identical (Euclidean distance coefficient $=0.0$ ) in the dendrogram based on leaf anatomy (Figure 5A). For example, cluster 1 joins $A$. parasiticum and Anthurium sp. nov., showing that similar anatomical traits occur on morphologically distinct species. Other species that are morphologically similar, as the pairs $A$. parasiticum X $A$. sellowianum and $A$. beyrichianum $\mathrm{X} A$. comtum appear as distinct groups in the cluster analysis (distance coefficient $=1.4$ and 2.0, respectively).

For the spathe anatomy (Fig. 5B) coefficients vary from 0.0 to 3.0, UPGMA 
values vary from 0.0 to 2.6 and cophenetic index is $0.9(p<0.01)$. Based on the spathe, taxonomically related species appear closer in the cluster analysis. Cluster 1 links the two varieties of $A$. harrisii, cluster 2 links $A$. beyrichianum and $A$. comtum, cluster 5 links A. parasiticum and $A$. sellowianum, while Anthurium sp. nov. is isolated from other species, in cluster 8 .

The comparative analysis between the dendrograms generated with leaf and spathe anatomy reveals a higher and better resolution for the spathe anatomical features, based not only on the higher distance and UPGMA coefficients but also on the maintenance of a clear dissimilarity on both the taxonomic and morphological analysis. Only the species $A$. harrisii was not considered similar to its two varieties $A$. harrisii var. consanguineum and A. harrisii var. assimile.

\section{Discussion}

Keating (2002) reported several useful leaf anatomical characters for diagnostic use in 380 species and 105 genera of Araceae. Despite the relatively large number of species of Anthurium ( 35 species) studied by Keating (2002), complementary studies are still need in order to improve the anatomical description of this large genus.

Keating (2002) classifies the epidermal cell walls in paradermal view as straight, undulate or extremely sinuous, and all these states of character occur in Anthurium. This character presented little variation here, with all studied species presenting straight to undulate walls.

For the species analyzed here, however, the epidermis of the spathe presented distinct anatomical characters in comparison to the leaf epidermis. Leaf epidermal cells were randomly distributed on paradermal view, but in the spathe they were distributed in rows parallel to the longitudinal axis of the organ. This disposition is usually found on leaves of grasses and other monocotyledons (Vieira \&
Mantovani 1995, Vieira et al. 2002). However Mayo (1986) shows short cells randomly distributed on spathe epidermis of Philodendron species.

Aroid species predominantly show smooth cuticles without ornamentation (Keating 2000), although striate cuticle occurs on the subfamily Pothoidae (Potiguara $\&$ Nascimento 1994) and in some Anthurium species (Keating 2002). The species analyzed here have smooth cuticle on leaves and striated on the spathe.

Mayo (1986) and Keating (2002) state that in some aroid genera the outline of the periclinal wall of the epidermal cells, as well as their height/width proportion, have diagnostic value for taxonomy. In the Anthurium species studied here the outer periclinal cell wall in both surfaces vary from straight to convex, not revealing differences in leaves. However, epidermal cells from the abaxial surface of some species as Anthurium sp. nov. are typically columnar and distinct from the tabular cells present on the abaxial surfaces of the other species.

Hypodermis is reported for the leaves of some species of Anthurium (Keating 2002), Philodendron alternans Schott and Philodendron crassinervium Lindley (Mantovani 1997). This tissue is absent in $A$. longifolium G. Don. (Mantovani 1999b) and A. bredemeyeri Schott (Rada \& Jaimez 1992). Periclinal cell divisions on the leaf adaxial epidermis are found here for some of the studied Anthurium species. Although ontogenetic studies were not carried out, the presence of such divisions suggests the possible occurrence of a multiple epidermis.

The number and distribution of the subsidiary cells from the stomata vary significantly for the Araceae. Keating (2002) reports brachyparacytic stomata and its variations, besides unipolar stomata for the family. All these types of stomata were found in the Anthurium species studied here, although only the amphibrachyparacytic, 
brachyparacytic and brachyparahexacytic types were reported by Keating (2002) for the genus Anthurium. The anomocytic type, considered rare for the Araceae (Grear 1973, Keating 2002), is only found in spathe in the present work.

According to Lindorf (1980), medium to large subsidiary cells characterize the brachyparacytic type of stomata on Anthurium, as observed here on leaves. On the spathe, short subsidiary cells are predominant.

Almost all aroid genera present stomata randomly distributed in leaves (Keating 2002), with exception of Gymnostachys and Lemnoideae, where the polar axis of the stomata is parallel to the leaf axis. Orientation and position of the stomata, respectively on paradermal and transversal view, vary between leaves and spathe in the species studied here. In paradermal view the orientation of leaf stomata is random. On the spathe, stomata orientation is regular and parallel to the spathe axis, as commonly seen in graminoids and other monocotyledons (Vieira \& Mantovani 1995). In transversal view, the stomata of the species studied here were positioned at the same level of epidermal cells in all species, but in A. sellowianum. A. parasiticum and Anthurium sp. nov. the stomata occurred above the epidermal cells on the abaxial surface of the spathe.

Few studies analyzed the potential use of the mesophyll features for taxonomic purposes in Araceae. Keating (2002, 2003) suggests a typology based on the occurrence of the palisade parenchyma and on types of aerenchyma, being the dorsiventral mesophyll typical for the aroid leaves (Mantovani 1997, 1999a, Keating 2000). For the Anthurium species analyzed here, the leaf mesophyll was always dorsiventral with large aerenchyma. On the other hand, the spathe mesophyll was always uniform, with compacted spongy cells, without aerenchyma. Only in A. regnellianum there are large intercellular spaces in the spathe. Mesophyll with elongated cells and large aerenchyma is cited for the spathe of Philodendron species (Mayo 1986, Sakuragui 1998).

Collenchyma and sclerenchyma are cited for Araceae (French 1997). Keating (2002) suggests five distinct types of collenchyma in aroids, based on its distribution on transversal view (caps over phloem, banded, banded interrupted, strands between vascular bundles, strands aligned with bundles). The banded and cap over phloem types are cited to Anthurium (Keating 2002). In the present group of species, we only found the banded type, on the abaxial surface of the midrib. Thickened cellulosic walls were found on cells adjacent to the adaxial surface of the midrib, but these could not be characterized as collenchyma due to their short length on longitudinal view (Esau 1977). In $A$. regnellianum, these collenchymatous cells of the midrib are substituted on the adaxial side by chlorenchymatic cells. This occurrence is cited by Keating (2002) for other Anthurium species. Although present in leaves, collenchyma was absent on spathes. However, Mayo (1986) cites the presence of collenchyma on spathes of Philodendron species.

Sclereids and fibres are reported for Araceae (Keating 2002). In Anthurium species, fibres are predominantly present as bundles sheaths, but caps of sclerenchyma over phloem or xylem occur in A. parisiense Bunting (Keating 2002). The leaves studied here only presented fibres forming vascular bundles. On the spathe, the fibres were always present as caps adjacent to the phloem, except for Anthurium sp. nov. whithout any fibres.

Keating (2002) and French \& Tomlinson (1981) reported collateral bundles to Araceae. In the species analyzed here the vascular bundles are characterized by several elements of proto and metaxylem, adjacent to a semicircular phloem, in the type described by Keating (2000) as type 1.

In relation to the occurrence of calcium 
oxalate crystals, all types (druses, raphides, sand, prismatics and, although rare, styloids) are cited to Araceae (Gemia \& Hillson 1985, Mantovani 1997, Keating 2003). Keating (2002) reports that two or more crystal types can occur simultaneously in the same organ in Araceae, with raphides and druses occurring in Anthurium species. Prychid \& Rudall (1999) demonstrate that the occurrence and distribution of crystals can be useful for taxonomic purposes in monocotyledons. Here druses occur not only in the mesophyll, but also in the epidermis of leaves and spathes, which is not cited by Keating $(2000 ; 2002)$ to Anthurium. Raphides were only seen on leaves, however Mayo (1986) shows the raphides in the spathes of Philodendron species.

Although secretory structures were reported by Lindorf (1980) and Keating (2000) for the genus Anthurium, they were not found in the species studied here.

The spathe is a reproductive structure with functional morphology related to the pollinization (Gottsberger \& Amaral 1984), but its similarity with leaves leads some authors to characterize them as "leaf-like structures" (sensu Grayum 1990). In fact, in some aroid genera such as Gymnostachys, Orontium and Pothoidium, the spathe is absent, being substituted in position and function by the apical leaf of the rizhome (Grayum 1990). These similarities resulted in anatomical comparisons between leaf and spathe.

Keating (2002) proposes trends of anatomical specializations in Araceae based on morphological and molecular analyses (French et al. 1995, Keating 2000). Following such propositions, we suggest that some anatomical characters presented in the spathe of the species studied (paralell venation, uniform mesophyll, presence of anomocytic stomata, lack of hypodermis and palisade parenchyma, poorly developed aerenchyma, absence of collenchyma and raphides) would be plesiomorphic characters in relation to the leaf anatomical characters (reticulated venation, dorsiventral mesophyll, absence of anomocitic stomata, presence of hypodermis and palisade, highly developed aerenchyma, presence of collenchyma and raphides).

These results could represent either distinct evolutionary rates for the leaf and spathe, or specific specialization trends for the anatomy of spathes. Interestingly, Mayo (1986) and Sakuragui (1998) report differentiated subepidermal cells, large aerenchyma, collenchyma and raphides in the spathe of Philodendron species, which is considered derived in relation to Anthurium (Grayum 1990, French et al. 1995). Complementary studies are necessary to test the hypotheses above.

Keating (2002) states that, although some anatomical characters with diagnostic value exist in Araceae, only a few are useful if analyzed separately, and that the best strategy for diagnosis in the family is the combination of a large number of characters. We conclude that, although some groups of characters could be obtained in leaves, spathe anatomical characters are more useful for diagnostic purposes in the Anthurium species analyzed here.

\section{Acknowledgments}

Authors are indebted to Dr. Thomas Croat for revision of the manuscript, Dr. Marcus Nadruz Coelho and Dra. Karen Lúcia Gama De Toni for the encouragement and advise, and Noa Magalhães for help with the plates. Authors thanks also the valuable suggestions from anonymous reviewers. The second author was sponsored by the Conselho Nacional de Pesquisa e Desenvolvimento (CNPq).

\section{Literature Cited}

Coelho, M. A. N. 2004. Taxonomia e biogeografia de Anthurium (Araceae). Seção Urospadix, subseção Flavescentiviridia. Tese de Doutorado. Universidade Fede- 
ral do Rio Grande do Sul, Porto Alegre, $321 \mathrm{p}$.

Embrapa-Snlcs-Ibama-1992. Identificação de limitações pedológicas e ambientais causadoras da degradação de áreas do Jardim Botânico do Rio de Janeiro. Publicação do Jardim Botânico do Rio de Janeiro. Série Estudos e Contribuições $\mathrm{n}^{\circ}$. 10. Rio de Janeiro. 101p.

Engler, A. 1905. Pothoideae. In: A. Engler (editor), Das Pflanzenreich IV. 23B (Heft 21), Engelmann, Leipzig. 330p.

Esau, K. 1977. Anatomy of seed plants. 2ed. John Wiley \& Sons, New York. 550p.

French, J. C. 1997. Vegetative anatomy. In: Mayo, S. J.; Borgner, J. \& Boyce, P. C. The genera of Araceae. Royal Botanic Gardens, Kew. Pp. 9-29.

French, J. C. \& Tomlinson, P. B. 1981. Vascular patterns in stems of Araceae: subfamily Monsteroideae. American Journal of Botany 68: 713-729.

French, J. C.; Chung, M. \& Hur, Y. 1995. Chloroplast DNA phylogeny of the Ariflorae. In: Rudall, P. J.; Cribb, P. J.; Cutler, D. F. \& Gregory, M. Monocotyledons: systematics and evolution. Academic Press, London. Pp. 255-275.

Galante, M. L. V. 1984. Geomorfologia: Jardim Botânico do Rio de Janeiro. Parque Lage, Rio de Janeiro. (mimeografado) 28pp.

Gemia, J. M. \& Hillson, C. J. 1985. The occurrence, type and location of calcium oxalate crystals in the leaves of fourteen species of Araceae. Annals of Botany 56: 351-361.

Gerrits, P. O. \& Smid, L. 1983. A new, less toxic polymerization system for the embedding of soft tissues in glycol methacrylate and subsequent preparing of serial sections. Journal of Microscopy 132: $81-85$.

Gottsberger, G. \& Amaral, A. 1984. Pollination strategies in Brazilian Philodendron species. Berichte Der
Deutschen Botanischen Gesellschaft 97: 391-410.

Govaerts, R.; Frodin, D. G.; Bogner, J.; Boyce, P.; Cosgriff, B.; Croat, T. B.; Gonçalves E. G.; Gayum, M.; Hay, A.; Hetterscheid, W.; Landolt E.; Mayo, S. J.; Murata, J.; Nguyen, V. D.; Sakuragui, C. M.; Singh, Y.; Thompson, S. \& Zhu, G. 2002. World checklist and bibliography of Araceae (and Acoraceae). Kew: Royal Botanic Garden. 560 p.

Grayum, M. H. 1990. Evolution and phylogeny of the Araceae. Annals of the Missouri Botanical Garden 77: 628-697.

Grear, J. W. 1973. Observations on the stomatal apparatus of Orontium aquaticum (Araceae). Botanical Gazette 134: 151-153.

Johansen, D. A. 1940. Plant microtechnique. Mc-Graw. Hill Book Co. Inc. New York, $523 \mathrm{p}$.

Keating, R. C. 2000. Collenchyma in Araceae: Trends and relation to classification. Botanical Journal of the Linnean Society 134: 203-214.

2002. Acoraceae and Araceae. In: Gregory, M. and Cutler, D. F. Anatomy of the monocotyledons. Oxford University Press, New York, 322p.

Keating, R. C. 2003. Leaf anatomical characters and their value in understand morphoclines in the Araceae. Botanical Review 68(4): 510-523.

Lindorf, H. 1980. Leaf structure of 15 shade monocotyledons of the cloud forest of Rancho Grande: 1. Bifacials: Araceae, Marantaceae, Musaceae. Memorias de la Sociedad de Ciencias Naturales "La Salle" 40(113): 19-72.

Mantovani, A. 1997. Considerações iniciais sobre a conquista do hábito epifítico na família Araceae. Universidade Federal do Rio de Janeiro, Programa de Pós-Graduação em Ecologia, 216p.

1999a. Leaf morphophysiology and distribution of epiphytic aroids along a 
vertical gradient in a Brazilian rain forest. Selbyana 20(2): 241-249. . 1999b. A method to improve leaf succulence quantification. Brazilian Archives of Biology and Technology 42(1): 9-14.

Mayo, S. J. 1986. Systematics of Philodendron Schott (Araceae) with special reference to inflorescence characters. PhD Thesis, 972 p. University of Reading, UK.

Mayo, S. J.; Borgner, J. \& Boyce, P. C. 1997. The genera of Araceae. Royal Botanic Gardens, Kew, 370p.

Mcdowel, E. M. 1978. Fixation and processing. In: Trump, B. F. \& Jones, R. T. Diagnostic electron microscopy. John Wiley \& Sons, New York. pp. 113-139.

O'Brien, T. P. \& McCully, M. E. 1981. The study of plants structure: principles and selected methods. Melbourne: Termarcarphi Pty. pp. 446-455.
Potiguara, R. C. V. \& Nascimento, M. E. 1994. Contribuição à anatomia dos órgãos vegetativos de Heteropsis jenmani Oliv. (Araceae). Boletim do Museu Paraense Emílio Goeldi 10(2): 237-247.

Prychid, C. J. \& Rudall, P. J. 1999. Calcium oxalate crystals in monocotyledons: a review of their structure and systematics. Annals of Botany 84: 725-739.

Rada, F. \& Jaimez, R. 1992. Comparative ecophysiology and anatomy of terrestrial and epiphytic Anthurium bredemeyeri Schott in a tropical Andean cloud forest. Journal of Experimental Botany 43: 723727.

Sakuragui, C. M. 1998. Taxonomia e filogenia das espécies de Philodendron, seção Calostigma (Schott) Pfeiffer no Brasil. Tese de Doutorado. São Paulo, Universidade de São Paulo. 238p.

Solereder, H. \& Meyer, F. J. 1928. Systematische anatomie der Monokotyledonen. Heft III, Gebruder Bornträeger, Berlin. Pp. 100-169.

Valentin, J. L. 2000. Ecologia Numérica: uma introdução à análise multivariada de dados ecológicos. Editora Interciência, Rio de Janeiro, 117p.

Vieira, R. C. \& Mantovani, A. 1995. Anatomia foliar de Deschampsia antarctica Desv. Revista Brasileira de Botânica 18(2): 207-220.

Vieira, R. C.; Gomes, D. M. S.; Sarahyba, L. S. \& Arruda, R. C. O. 2002. Leaf anatomy of three herbaceous bamboo species. Brazilian Journal of Biology 62(4): 907922. 
